\title{
Can Confucianism Save Liberalism? Should It?
}

\author{
Mateusz Janik \\ Assistant Professor of Institute of Political Studies, Polish Academy \\ of Sciences, Poland \\ janikm@protonmail.com
}

Bai Tongdong, Against Political Equality: The Confucian Case. Princeton: Princeton

University Press, 2019. 344 pages, ISBN: 978-o691195995.

Chinese Confucianism is as diverse as a millennium-old intellectual tradition can be. However, the common ground for various Confucian positions stems from the shared corpus of texts and the questions that follow from it. One of these questions concerns continuity, which-especially in the case of political philosophy_resonates with the image of China as a state-based civilization rooted deeply in its history.

Bai Tongdong's latest book, Against Political Equality: The Confucian Case, is an original voice in the ongoing debate on the contemporary application of Confucianism. Its point of departure is philosophical continuity, taken not as an assumption but, rather, as a question (how should early Confucian texts be read philosophically?). Bai has been engaged in this debate for over a decade now, starting with his work on the political stakes that shaped the historical reality of the early Chinese state. ${ }^{1}$

The originality of the argument presented in Against Political Equality follows from Bai's claim that classical Chinese philosophy was developed amid a historical shift to a society that, in many respects, resembled that of early modern Europe. This view was presented in his 2012 book China: The Political Philosophy of the Middle Kingdom, ${ }^{2}$ and it sets the groundwork for the main argument in his latest book, as it offers an effective methodological vehicle for developing a comparative perspective. It also allows the author to voice

1 Bai Tongdong 白䑣東, Jiubang xinming: Gujin zhongxi canzhao xia de gudian Rujia zhengzhi zhexue 舊邦新命——古今中西參照下的古典儒家政治哲學 [A New Mission of an Old State: the Comparative and Contemporary Relevance of Classical Confucian Political Philosophy] (Beijing: Beijing daxue chubanshe, 2009).

2 Bai Tongdong, China: The Political Philosophy of the Middle Kingdom (London: Zed Books, 2012). 
a critique of liberal democracy as well as to distance himself from a broader current of New Confucianism, revived recently by scholars such as Jiang Qing 蔣慶 ${ }^{3}$ as well as Daniel A. Bell and Wang Pei 汪沛. ${ }^{4}$

Against Political Equality has nine chapters that guide readers through the three main steps in Bai's argument. The first step sets the comparative framework by claiming that Confucianism in the Spring and Autumn [770-476 BCE] and Warring States [475-221 $\mathrm{BCE}]$ periods should be seen as a response to a shift from feudalism to modernity. This shift was marked by dissolution of the clan-based political authority and intensification of social mobility, creating new political solutions and new ways to think about the sociopolitical body as a whole. According to Bai, Confucian thinkers in the pre-imperial period found themselves in conditions that structurally resembled the rise of the modern state system in Europe, and thus their answers can be justifiably compared to those given by Western thinkers in the post feudal period. The second step follows from the argument that although liberal democracy remains a globally hegemonic political model, it is far from the last stage of historical development. Bai points out some problems in the Western political model, ranging from questions of legitimacy and political agency to education and citizens' ability to participate in decision making. The third step applies the Confucian responses to the challenges of modernity in order to reform the institutional and ideological frameworks of liberal democracy. The resulting "Confucian hybrid regime," when applied to Western democracy, would strengthen the liberal side but undermine the democratic side, offering a more communityoriented and meritocratic approach.

Chapter 1, "Why Confucianism? Which Confucianism?" reveals the foundation of Bai's philosophical project at the methodological level. The reader will find here some revealing explanations of how Bai reconstructs the textual tradition of Confucianism-a step often missing from the comparative approaches that tend to take the Confucian corpus for granted. Bai attempts to read the Confucian canonical works philosophically. This means that he approaches them as texts that engage reflexively in discussing "philosophical problems" (i.e., genuinely unsolvable challenges to human existence that transcend particular moments in time and space; p. 10). As such, these texts are taken as a whole and read systematically, even though this kind of a holistic approach has been challenged (p. 14). However, it is a pity that the book does

3 Jiang Qing, A Confucian Constitutional Order: How China's Ancient Past Can Shape Its Political Future, ed. Daniel Bell and Fan Ruiping (Princeton: Princeton University Press, 2012).

4 Daniel Bell and Wang Pei, Just Hierarchy: Why Social Hierarchies Matter in China and the Rest of the World (Princeton: Princeton University Press, 2012). 
not provide a similar explanation of the liberal tradition, which is far from a closed system of ideas. Bai has a certain textual tradition in mind in referring to John Locke, John Stuart Mill, and John Rawls, yet interweaves them into the narrative without enough methodological caution. Thus, whereas "can early liberal texts be read philosophically?" is a provocative question, the answer to it might turn out to be even more interesting than the answer to the question concerning a philosophical reading of Confucian texts.

Chapter 2, "Confucianism on Political Legitimacy: For the People, of the People, But Not by the People," explores the early Confucian response to Chinese modernity in the pre-imperial period. Here, Bai stresses an important point made by other proponents of Confucianism, such as Jiang Qing - namely, that the core question of early Confucian political discourse is not sovereignty but, rather, legitimacy (p. 34). This has important consequences, particularly with respect to the alleged democratic tendencies found in Mencius as well as in how Confucian moral and political precepts should be interpreted. Bai takes a very open approach to an aspect of Confucianism that is sometimes neglected, namely, that it was developed as a discourse addressed to the ruling classes (p. 45). He sees this not as a limitation but as an advantage. It is interesting to follow his consistent defense of political meritocratic elitism and critique of the "one person, one vote" system on this ground. Nevertheless, the binary setting of the entire book becomes a burden here. As a confrontation between liberal and Confucian traditions, it excludes other perspectives-not only radical democratic antiliberal movements in Europe that had a tremendous influence on the development of the liberal tradition but also Daoist critiques of the Confucian political model that might put the question of authority and political legitimacy into a broader perspective.

Chapters 3 and 4 discuss the Confucian "hybrid regime," which is Bai's response to the limitations of liberalism and Western democracy. In Chapter 3 , "A Confucian Hybrid Regime as an Answer to Democratic Problems," the blending of democracy and meritocracy is defended as a proper response that allows a more stable political model in which social mobility and political participation are reframed along the lines of education and the development of moral cultivation. The argument in favor of a hybrid regime is based on a political reading of Mencius. Nevertheless, Bai's point is that a political perspective blending together democratic and authoritarian elements is universally applicable. Chapter 4, "The Superiority of the Confucian Hybrid Regime Defended," addresses some of the possible critiques of the Confucian corrections of the liberal democratic model - in particular, the accusation that it undermines equality, which is supposed to be one of the foundations of liberal democracy (pp. 98-102). In the conclusion to this chapter, Bai offers a good summary of 
his argument so far: in general, Confucian political theory provides not only a model for more balanced political institutions but also a regulative horizon that is more realistic than the one offered by liberal democrats.

Chapter 5, "Compassion as the New Social Glue in the Society of Strangers," contains a philosophically intriguing defense of the Confucian version of the idea of universal care and humanness, seen as a response to the dissolution of social relations during Spring and Autumn and Warring States periods. A deeper metaphysical structure of the Confucian project is at work here, and Bai skillfully shifts between early Confucian and neo-Confucian authors, showing how the universalist claims, concerning the care for others, remain hierarchical despite their inclusive features. The strength of this chapter follows in part from the fact that Bai develops his interpretation of compassion, care, and humanness from the Confucian tradition, without an attempt to fit it into the liberal philosophical discourse (pp. 125-28). This is the heart of the book. It offers insight into the Confucian understanding of social relations and offers a convincing political reformulation of the moral philosophy found in Confucian texts.

This discussion continues in Chapter 6, "Conflict in the Expansion of Care: The Private versus the Public." Here, Bai employs the philosophical apparatus that he constructed in earlier chapters. He argues that the division of society into two spheres (public and private) can be positively transformed by a more hierarchical order involving a gradual stratification of society. Individuals and groups that comprise such a society would be linked together by an affective network of relations inspired by the concept of universal compassion (p. 139).

Chapter 7, "Tian Xia: A Confucian Model of National Identity and International Relations," takes this argument even further, showing how it can be applied to international relations by exploring the implications of Confucian moral teachings on the idea of "All under Heaven" (pp. 184-87) one of the most important terms in Chinese political thought. The Confucian model of international relations is presented as an alternative to various modern political theories of nation-state interests. In this context, Bai also argues that embracing the Confucian hybrid regime would allow the Chinese government to relax its dependence on nationalist ideology, which remains one of the biggest obstacles to its peaceful rise in the global arena (p. 213).

The last two chapters conclude the argument by pointing to the possibility of a Confucian concept of rights, based in particular on the Mencian approach to justice. In Chapter 8, "Humane Responsibility Overrides Sovereignty: A Confucian Theory of Just War," Bai reconstructs Mencius' views on justified war, showing that, despite many differences, the Confucian concept of justice can be elaborated as a social discourse with some merit in the context of modern 
social and political conflicts (pp. 226-29). In this way, he lays the ground for the argument developed in Chapter 9, "A Confucian Theory of Rights." It is somewhat surprising that, in this chapter, Bai seems to return to a "compatibility claim" renounced in the introduction (p.xi).

Throughout the book, Bai consistently avoids argumentation focused on showing how Confucianism can be integrated into the liberal political discourse, offering, instead, various Confucian alternatives to the challenges faced by liberalism. The last two chapters seem to be written in a more conciliatory manner. However, the argument that Confucians can develop a concept of rights that is not in direct conflict with its liberal-democratic counterpart seems to be a strategic statement. It allows Bai to make the argument that, by applying the Confucian approach to the concept of rights, one can offer the meritocratic corrections of the liberal discourse.

Finally, in the "Postscript," Bai makes some general remarks concerning the applicability of the Confucian perspective to issues that pose moral and existential threats to humanity, such as climate change and unbalanced technological development. The book closes with a brief consideration of the very possibility of challenging the liberal-democratic model of political institutions under the current sociohistorical conditions.

A couple of points need to be mentioned concerning the way in which Bai constructs his understanding of liberalism and Confucianism. Both notions should be seen as philosophical-political projects, rather than as realized policies. Bai rarely confronts the fact that both liberal democratic and Confucian political institutions are already complex "hybrid regimes" that incorporate a variety of traditions. However, one might argue that, just as some of the early Confucian ideas concerning universal compassion can be seen as responses to Mohist critiques of Confucian elitism, many of the modern democratic institutions developed along social struggles and pressures that originated outside the liberal tradition. The fact that Against Political Equality uses certain "ideal types" of political discourses is something that might be easily missed by readers who trust frequent references to historical realities and actual political solutions. Bai swiftly shifts from philosophical arguments found, for example, in John Rawls's work to the realities of US policies or from actual social processes that shaped the Confucian discourse to philosophical arguments found in the Mencius. This should not be seen as a disadvantage - the argument concerning the shift from feudalism to early modernity at the dusk of the Zhou dynasty [1046-256 вСЕ] is a great piece of a comparative study of historical processes that influence philosophical discourse. Frequent references to political realities in the United States and Europe are also important elements of 
the rhetorical layer of the book, as they prevent it from becoming a dry philosophical lecture.

Nevertheless, one cannot but wonder at how precisely crafted the illustrations of Bai's philosophical argument are. He criticizes liberal elements of modern representative democracy in a way that is inherent to the liberal discourse itself, while refraining from challenging it as a political doctrine. For example, he questions the "one person, one vote" principle not as politically invalid but, rather, as an idea that does not address some systemic inequality carved into the very edifice of a democratic political system (pp. 54-56). A similar mode of argumentation can be found in his discussion concerning individual as well as the private and public sphere (pp. 138-40). In these contexts, Confucian notions such as meritocracy and universal care appear to be augmentations, solving issues that liberalism is supposedly incapable of addressing. This is the idea behind one of the central political concepts presented in the book, namely, the abovementioned "Confucian hybrid regime."

I believe there are two reasons for Bai's method of confronting the liberal tradition. In Chapter 1, Bai points out that the ideological hegemony of liberal democracy is becoming less obvious (p. 1). Nevertheless, he frames his argument in the context of the optimism that followed Francis Fukuyama's claim concerning the end of history and the rise of the perpetual age of liberal democracy (p. 28). At the structural level, this allows Bai to develop a grand narrative in which Confucianism and liberalism are introduced as two great traditions of long standing that can engage in dialogue. But in his final remarks, he mentions yet another reason for the reservation in his critique of liberalism: "[S]ince liberal democratic models have been given an almost sacred status, any perceived challenge to them often results in complete neglect and even hostile reactions" (p. 289).

However, this argument seems misdirected because of the existence of a rich tradition of critical approaches that point out the discrepancies between liberal discourse and the actual atrocities that made it possible and are made possible by it. One great study of "blindness" to colonial violence among Western thinkers from Locke to Hegel is Susan Buck-Morss's book Hegel, Haiti, and Universal History. ${ }^{5}$ Buck-Morss shows that philosophical discourse on modernity is ill-suited to address political events that challenge the power structure supporting its universalist claims (e.g., the Haitian revolution). Modern liberal claims to legitimacy as a normative horizon of the globalized world are also discussed in Ariella Azoulay's recent book Potential History:

5 Susan Buck-Morss, Hegel, Haiti, and Universal History (Pittsburgh: University of Pittsburgh Press, 2009). 
Unlearning Imperialism. ${ }^{6}$ Bai chose a much more cautious strategy of debating the limitations of liberalism, aimed at convincing liberals to adopt certain Confucian solutions, rather than disarming them through a profound critique of the very premises of the liberal narrative. To be sure, he often gives voice to Western thinkers who challenged liberal tradition, such as Nietzsche (e.g., pp. 115-19, 177) and even shows that liberal authors have acknowledged the limitation of their ideas (in particular, Rawls, pp. 61 and 268).

It would be still possible to provide a much more nuanced image of the limits of liberal discourse even by means of far less confrontational approaches than those offered by Azoulay or Buck-Morss - with respect to a theory of rights, ${ }^{7}$ political participation and recognition, ${ }^{8}$ or even concepts of just war. ${ }^{9}$ What these books have in common with Bai's project is that they take seriously the claims of liberal thinkers and argue that the democratic institutions in their current form do not satisfy them. At the same time, their authors are much more skeptical about the idea of saving liberalism from itself than Bai seems to be. Against Political Equality would benefit greatly from an additional chapter discussing such challenges to liberalism-embedding the Confucian case much more in an ongoing debate concerning the alternatives and transformations in Western political discourse over the three decades after Fukuyama's claim.

The fact that Bai does not include this synoptic analysis, which would situate Confucian arguments in a broader current of debates, does not make his argument any less engaging. His Confucian answer might seem surprising in the sense that it offers a perspective in which the internal conflicts in liberalism are acknowledged and turned into cornerstones of a renewed political edifice. Thus, the argument that liberal democracy is still prone to issues concerning equality is reshaped into a question of how inequality can be institutionalized in a way that it contributes to society. The problematic status of political elites is rearticulated as a question of how elites can be better integrated into society as a whole. One might argue that this Confucian amendment allows liberalism to confront its own structural presuppositions in a more honest way by acknowledging its own propositional-performative contradictions. Such a reading underscores the characteristic feature of Bai's philosophical project, namely, the fact that Against Political Equality is not a Confucian defense of hierarchies and meritocracy but, rather, the application of Confucian frugality as a philosophical method. The author gives liberals a helping hand by

6 Ariella Azoulay, Potential History: Unlearning Imperialism (New York: Verso Books, 2019).

7 Seyla Benhabib, The Rights of Others: Aliens, Residents, and Citizens (Cambridge: Cambridge University Press, 2004).

8 Nancy Fraser, Redistribution or Recognition? A Political-Philosophical Exchange (New York: Verso Books, 2003).

9 Judith Butler, Frames of War: When Is Life Grievable? (New York: Verso Books, 2009). 
pointing the way for virtue to be reintroduced into the fabric of political practice. Taken as such, Bai's book is an example of comparative scholarship that consistently follows the "single thread binding it all together" (Analects 4:15), weaving another chapter in the Confucian tapestry.

\section{Works Cited}

Azoulay, Ariella. Potential History: Unlearning Imperialism. New York: Verso Books, 2019.

Bai Tongdong 白肜東. Jiubang xinming: Gujin zhongxi canzhao xia de gudian Rujia zhengzhi zhexue 舊邦新命一古今中西參照下的古典儒家政治哲學 [A New Mission of an Old State: The Comparative and Contemporary Relevance of Classical Confucian Political Philosophy]. Beijing: Beijing daxue chubanshe, 2009.

Bai Tongdong. China: The Political Philosophy of the Middle Kingdom. London: Zed Books, 2012.

Bell, Daniel, and Wang Pei. Just Hierarchy: Why Social Hierarchies Matter in China and the Rest of the World. Princeton: Princeton University Press, 2020.

Benhabib, Seyla. The Rights of Others: Aliens, Residents, and Citizens. Cambridge: Cambridge University Press, 2004.

Buck-Morss, Susan. Hegel, Haiti, and Universal History. Pittsburgh: University of Pittsburgh Press, 2009.

Butler, Judith. Frames of War: When Is Life Grievable? New York: Verso Books, 2009.

Fraser, Nancy. Redistribution or Recognition? A Political-Philosophical Exchange. New York: Verso Books, 2003.

Jiang Qing. A Confucian Constitutional Order: How China's Ancient Past Can Shape Its Political Future. Edited by Daniel Bell and Fan Ruiping. Princeton: Princeton University Press, 2012. 